\title{
CARA PEMBUATAN BOKASHI ECENG GONDOK
}

\author{
${\text { Farida Aryani1 }{ }^{*} \text {, Sri Rustianti }{ }^{2} \text {, Cece Gusti Kartina }}^{3)}$ \\ 1,2) Dosen Fakultas Pertanian Unihaz Bengkulu \\ 3) Mahasiswa Fakultas Pertanian Unihaz Bengkulu \\ *) Corresponding author: faridaaryani781@gmail.com
}

\begin{abstract}
ABSTRAK
Desa Sumber Rejo Transad merupakan salah satu desa yang terletak di Kecamatan Bermani Ulu, Kabupaten Rejang Lebong dimana sebagian besar penduduknya bermata pencairan sebagai petani. Bercocok tanam merupakan sumber pendapatan mereka, semakin meningkatnya produksi pertanian yang diperoleh maka kesejahteraan masyarakat semakin meningkat. Berbagai usaha dilakukan oleh masyarakat tani di Desa Sumber Rejo Transad untuk meningkatkan produksi pertanian mereka, antara lain dengan penggunaan pupuk an organik. Petani tidak menyadari bahwa penggunaan pupuk an organik dapat menimbulkan dampak negatif, antara lain dapat menyebabkan kepadatan tanah, meningkatnya biaya produksi, serta terjadinya pencemaran lingkungan. Mengingat hal tersebut maka perlu mengalihkan kebiasaan masyarakat yang mengutamakan penggunaan pupuk an organik ke penggunaan pupuk organik berupa bokashi. Cara yang efektif untuk mengalihkan kebiasaan masyarakat menggunakan pupuk organik adalah melalui penyuluhan / pelatihan, dengan metode, yaitu : 1) Pendidikan / penyuluhan tentang pupuk organik dan pupuk an organik serta bagaimana teknik pembuatan bokashi eceng gondok; 2) Pelatihan cara pembuatan bokashi eceng gondok, dimana eceng gondok yang sangat banyak di perairan Desa Sumber Rejo Transad Kecamatan Bermani Ulu. Melalui penyuluhan / pelatihan dalam rangka pengabdian masyarakat ini telah meningkatkan wawasan masyarakat tani tentang pupuk organik dan dampak yang ditimbulkan terhadap lingkungan, pupuk an organik serta pembuatan bokashi eceng gondok selanjutnya dapat meminimalisir pembiayaan operasional dan pencemaran lingkungan akibat pemakaian pupuk an organik.
\end{abstract}

Kata Kunci : Eceng Gondok, Bokashi, Pupuk Organik, Pupuk an Organik

\section{PENDAHULUAN}

\subsection{Latar Belakang}

Tumbuhan eceng gondok merupakan tumbuhan yang dapat menganggu kegiatan masyarakat disekitar perairan karena dapat menyebabkan pandangkalan, menyumbat saluran irigasi, memperbesar kehilangan air serta mempersulit transportasi perairan, selain itu menganggu biota yang hidup di dalam air karena menghambat masuknya cahaya kedalam badan air.

Pertumbuhan eceng gondok yang sangat cepat tersebut membuat masyarakat sulit untuk mengendalikannya, biasanya masyarakat mengendalikan eceng gondok dengan cara manual yaitu membuang eceng gondong.
Eceng gondok mempunyai kelebihan selain pertumbuhannya yang cepat, dapat menyerap berbagai zat yang berbahaya yang dapat mencemari perairan, seperti: logam beracun, cemaran organik, buangan industri, buangan pertanian dan buangan rumah tangga (Rahmawati, dkk;2003).

Eceng gondok dapat mencapai ketinggian antara 40-80 cm dengan daun yang licin sepanjang 7-25 cm. tumbuhan eceng gondok terdiri dari helaian daun pengapung, leher daun, ligula akar, akar rambut, ujung akar, daun stolon. Stolon dijadikan sebagai organ pengembangbiakan vegetatif (Nursyakia, 2014).

Di perairan yang mengandung nitrogen tinggi, eceng gondok memiliki daun yang relative lebar dan berwarna hijau tua, sebaliknya di perairan yang mengandung 
nitrogen rendah, eceng gondok memiliki daun yang relative kecil dan berwarna kekuning-kuningan, karena pertumbuhan eceng gondok tergantung dari nutrisi yang tersedia dari cahaya matahari untuk melaksanakan proses fotosintesis (Replay, dkk, 2006).

Kecepatan tumbuh eceng gondok sebagai gulma dapat merusak lingkungan perairan. Eceng gondok baik tumbuh didaerah tropis, yang memerlukan cahaya matahari yang cukup, suku optimal $25-30^{\circ} \mathrm{c}$. eceng gondok dapat hidup ditempat yang mempunyai keasaman $(\mathrm{pH})$ air 3.5-10, pertumbuhan yang terbaik pada $\mathrm{pH}$ air optimal 4.5-7 (Muktar dan Ahmad, 2008).

Selain memberi dampak negatif eceng gondok juga memberikan manfaat sebagai bahan baku pembuatan bokashi atau kompos. Kandungan unsur hara pada tumbuhan eceng gondok cukup besar. Hasil analisis kimia dari eceng gondok dalam keadaan segar adalah $0.28^{\circ} \mathrm{N}$ total; $36.59 \%$ bahan organik; $21.23 \%$ C-organik; $0.016 \%$ p total (Tangio, J.S, 2013). Selain itu kandungan dalam eceng gondok adalah; kalsium, asam sianida, tri terpenoid dan alkohol (Dian-Putri, 2018).

Pupuk adalah bahan yang diberikan kedalam tanah, pupuk dapat berupa pupuk organik maupun pupuk an organik. Pemberian pupuk tersebut dengan tujuan menggantikan kehilangan unsur hawa dan dalam tanah akibat dari panca, tercuci serta meningkatkan produksi tanaman dalam keadaan faktor lingkungan yang baik (Sutejo dan Kartosapoetra, 2002). Pupuk organik merupakan pupuk yang berasal dari pelapukan sisa makhluk hidup seperti tanaman, hewan, dan limbah organik. Pupuk organik mengandung unsur hara yang lebih lengkap dibandingkan dengan pupuk an organik. Sehingga penggunaan pupuk organik lebih menguntungkan disbanding dengan pupuk an organik selain itu pupuk an organik dapat menimbulkan sisa asam organik di dalam tanah dan pemberian yang berlebihan dapat merusak tanah serta pencemaran.

Bokashi merupakan pupuk kompos yang di buat dengan cara fermentasi. Bahan bokashi terdiri dari sisa-sisa tanaman, kotoran hewan, sampah dapur atau campuran dengan memanfaatkan aktivitas mikroorganisme efektif (EM.4) sebagai decomposer (Anonim, 2012).

Desa Sumber Rejo Transad, Kecamatan Bermani Ulu merupakan daerah yang subur dengan perairan yang baik dan banyak ditumbuhi eceng gondok, hal tersebut merupakan kendala bagi petani dalam melaksanakan usaha tani, sehingga perlu dicari jalan keluarnya bagaimana pemanfaatan eceng gondok tersebut.

Berdasarkan permasalahan tersebut diatas maka perlu dilakukan penyuluhan dan pelatihan cara pembuatan bokashi eceng gondok bagi masyarakat tani di Desa Sumber Rejo Transad, Kecamatan Bermani Ulu.

\subsection{Perumusan Masalah}

a. Pengendalian eceng gondok secara manual memerlukan waktu, tenaga dan biaya yang besar.

b. Penggunaan pestisida dalam pengendalian eceng gondok memerlukan biaya yang besar dan dapat menyebabkan pencemaran lingkungan.

c. Kurangnya pengetahuan masyarakat tani dalam hal pembuatan bokashi eceng gondok.

\section{METODE KEGIATAN}

\subsection{Solusi Permasalahan Masyarakat Tani}

Dengan kondisi perairan yang baik dan ditutupi oleh tumbuhan eceng gondok, masyarakat harus bisa mengolah tumbuhan eceng gondok sehingga dapat bermanfaat bagi masyarakat. Dengan melaksanakan penyuluhan dan pelatihan pembuatan bokashi eceng gondok dapat meningkatkan pengetahun dan ketrampilan petani untuk memanfaatkan tumbuhan eceng gondok, sehingga pengendalian eceng gondok tidak membutuhkan waktu, tenaga dan biaya yang besar, serta tidak perlu penggunaan pestisida sintetik yang dapat menyebabkan pencemaran lingkunga.

\subsection{Tahapan Pelaksanaan Pengabdian}

Pengabdian dilakukan pada masyarakat tani, Desa Sumber Rejo Transad, Kecamatan 


\section{Ourrats}

Bermani Ulu pada tanggal 7 Maret sampai dengan 23 Maret 2020.

\section{a. Penyuluhan}

Untuk meningkatkan pengetahuan masyarakat tani tentang cara pembuatan bokashi eceng gondok.

\section{b. Pelatihan}

Pada kegiatan ini masyarakat tani mempraktekkan cara pembuatan bokashi eceng gondok

\subsection{Cara Pembuatan Bokashi}

a. Bahan-bahan yang digunakan

1. Eceng gondok

2. $\mathrm{Em} 4$

3. Kotoran sapi

4. Sekam

5. Gula

6. Air

b. Alat-alat yang digunakan

1. Parang

2. Cangkul

3. Karung plastik

4. Thermometer

c. Proses pembuatan bokashi eceng gondok

1. Eceng gondok dipotong-potong menggunakan parang dengan ukuran kecil-kecil 1-5 cm, olahan eceng gondok dijemur untuk menurunkan kadar airnya (sampai layu).

2. Potongan eceng gondok yang sudah dijamur dicampur dengan pupuk kandang kotoran sapid an sekam dengan perbandingan $1: 1: 1$, kemudian diaduk hingga rata.

3. Em4 dan gula pasir dilarutkan ke dalam air bersih dengan konstruksi $250 \mathrm{ml} \mathrm{Em} 4 / 1$ liter air dan ditambah satu sendok makan gula pasir.

4. Campuran eceng gondok yang telah diaduk rata dengan kotoran ternak, sekam tersebut disiram dengan larutan Em4 yang ditambah gula pasir, kemudian diaduk sampai rata.
5. Setelah selesai, campuran dimasukkan ke dalam karung dibiarkan selama lebih kurang 2 minggu ditempat yang bersih. Campuran diaduk 2 hari sekali.

6. Setelah 2minggu, bokashi eceng gondok sudah matang dan siap digunakan untuk tanaman sebagai pupuk.

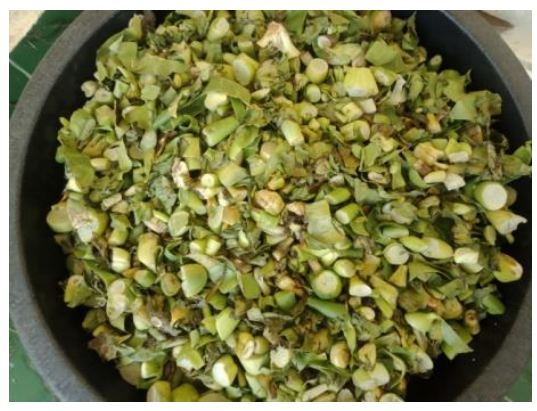

Gambar 1. Cercahan Eceng Gondok

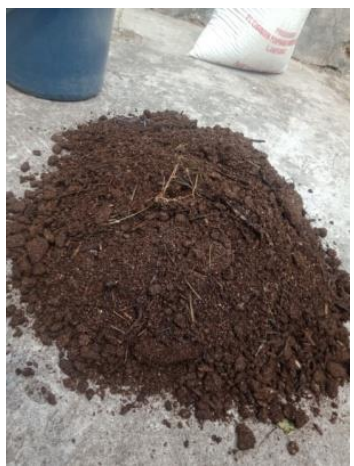

Gambar 2. Pupuk Kandang Kotoran Sapi

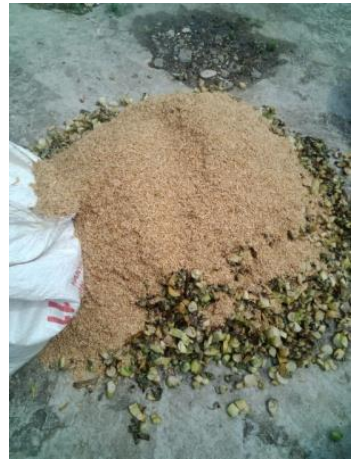

Gambar. 3 Percampuran Eceng Gondok dan Pupuk Kandang dan Sekam

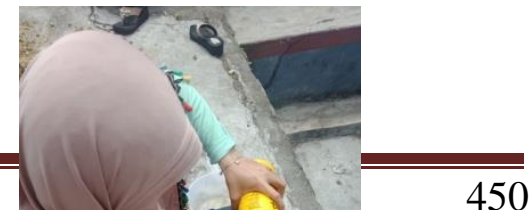


Gambar 4. Pembuatan Larutan Em4, Air dan Gula

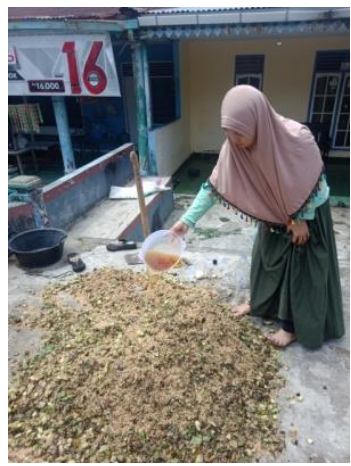

Gambar 5. Penyiraman Campuran, Pupuk Kandang, Sekam dengan

Larutan EM4, Air dan Gula

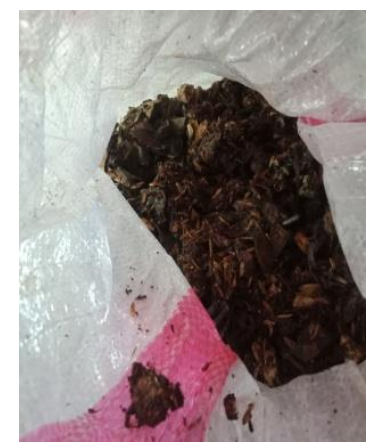

Gambar 6. Semua Bahan yang sudah diaduk dimasukkan dalam Karung

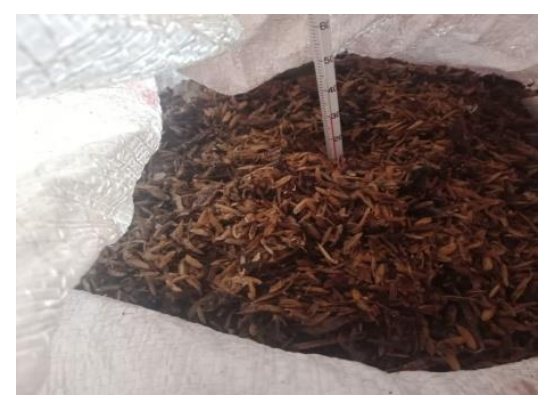

Gambar 7. Pengukuran Suhu Bokashi

\section{HASIL DAN PEMBAHASAN}

Pelaksanaan kegiatan pengabdian masyarakat tani di Desa Sumber Rejo Transad, Kecamatan Bermani Ulu mengikuti sebagian dari masyarakat tani yang dilaksanakan tanggal 7 Maret sampai dengan 23 Maret 2020. Hanya sebagian masyarakat tani yang hadir supaya informasi yang dapat lebih efektif dan efisien, sehingga masyarakat yang mengikuti pengabian dapat menyampaikan pengetahuannya dan keterampilan yang diterimanya pada saat mengikuti kegiatan pengabdian masyarakat, baik penyuluhan maupun pelatihan. Tempat pelaksanaan kegiatan tidak menjadi permasalahan karena masyarakat petani bersedia menyiapkan rempat dan bahan untuk pembuatan Bokashi, serta bahan-bahan dan alat-alat yang diperlukan, untuk pelaksanaan kegiatan.

Bokashi sudah dapat dipanen setelah dua minggu dengan ciri-ciri :

1. Bokashi sudah berwarna coklat kehitaman.

2. Tekstur mengumpal ketika dikepal.

3. Suhu $30^{\circ} \mathrm{C}$ stabil.

Hal tersebut sejalan dengan pendapat Hajama (2014) bahwa bokashi dapat dipanen setelah 2 minggu dengan ciri sudah berwarna coklat kehitaman, mengepal, suhu $30^{\circ} \mathrm{C}$.

Berdasarkan evaluasi selama berlangsungnya kegiatan pengabdian pada masyarakat berjalan dengan baik, yaitu sebagai berikut :

1. Dengan adanya pengolahan eceng gondok menjadi bokashi dapat meminimalisir pencemaran lingkungan perairan di Desa Sumber Rejo Transad.

2. Adanya peningkatan pengetahuan dan ketrampilan masyarakat tani di Desa Sumber Rejo Transad.

3. Kegiatan ini dapat memotivasi masyarakat tani di Desa Sumber Rejo Transad

\section{PENUTUP}

\subsection{Kesimpulan}


1. Kegiatan pengabdian masyarakat dapat memberikan pengertian kepada masyarakat tani di Desa Sumber Rejo Transad tentang pentingnya melestarikan lingkungan perairan.

2. Kegiatan pengabdian masyarakat dapat direspon dengan baik oleh masyarakat petani.

3. Pelaksanaan kegiatan pengabdian masyarakat dapat meningkatkan wawasan, pengetahuan dan ketrampilan dalam pembuatan bokashi eceng gondok.

\subsection{Saran}

1. Perlu penyuluhan / pelatihan pembuatan bokashi yang lebih variatif, yang bahan-bahannya banyak terdapat disekitar kita, contohnya : sisa-sisa dapat rumah tangga, sisa-sisa tanaman, kotoran hewan.

2. Anggota masyarakat tani dapat menjadi penyebar pengetahuan dan ketrampilan tentang pembuatan bokashi eceng gondok.

\section{DAFTAR PUSTAKA}

Anomin, 2012. Cara Membuat Pupuk Bokashi. Akan Tani. Yogyakarta.

Dian-Putri.2018. Cara Membuat Pupuk. Eceng Gondok (https://ilmubudidaya.com/author/dian -putri)

Hajama.2014, Studi Pemanfatan Eceng Gondok sebagai bahan Pembuatan Pupuk KOmpos dengan Menggunakan Aktivator Em4 dan Mol Serta Porspek Pengembannya. Skripsi. Makasar: Fakultas Teknik Universitas Hasanuddin.

Muhtar, dan Ahmad. 2008. Tugas akhir: Penggunaan Tanaman Eceng Gondok (Eichonid erassipees) sebagai PreTreatment Pengolahan Air Minum pada Air Selokan Mataram. Jurusan
Teknik Lingkungan Fakultas Teknik Sipil dan perencanaan Universitas Islam Indonesia. Yogyakarta.

Nursyakia. 2014. Laporan Akhir; Studi Pemanfaatan Eceng Gondok sebagari Pembuatan Pupuk Kompos dengan Menggunakan Aktivator EM4 dan Mol. Serta Prospek Pengembangan UNHAS Makasar.

Rahmawati, F. Pranoto, dan Ita Aryumani, N.2003. Jurnal: adsorbs zat warna tekstil remanzol yellow fg pada limbah balik oleh eceng gondok dengan activator $\mathrm{NaOh}$. Alchemy, vol 12, No. 2F. MIPA UNJ.

Replay.B.S, Muller, E, and Behenna, M. 2006. Biomass and Photosyntetic productivity of water hiyacinth as effected by nutrient supply and mired biocontrol. Biological control 29, 392400.

Sutedjo, dan kartosapoetra 2002. Pengantar Ilmu Tanah, Terbentuknya tanah dan Tanah Pertanian. Penerbit Rineka. Jakarta.

Tangio.J.S. 2013, Adsorpasi Logam Timbal $(\mathrm{Pb})$ dengan menggunakan iomassa eceng gondok (Eichonia (crassipes) Jurnal Entropi, volume VII, No. 1, Februari 2013. 